\title{
RESISTING INVASIONS: INDIGENOUS PEOPLES AND LAND RIGHTS BATTLES IN MABO AND TERRA VERMELHA
}

\author{
Aline Frey \\ University of Queensland \\ Brisbane, AU
}

In early times the whites lived like us in the forest, [...]but once they created tools, machines, cars and planes, they became euphoric and said: "We are the only people to be so ingenious, only we know how to produce machines and merchandise." That is when they lost all wisdom. First they damage their own land, before going off to work in other lands in order to endlessly create their merchandise. And they never stopped to ask: "If we destroy the earth, will we be able to create another one?". Davi Kopenawa Yanomami ${ }^{1}$

\begin{abstract}
This article examines two feature films, focusing on the link between Indigenous cinema, environmental preservation and land rights. The first film is Mabo (2012) directed by Aboriginal filmmaker Rachel Perkins. It centres on a man's legal battle for recognition of Indigenous land ownership in Australia. The second film is Terra Vermelha (Birdwatchers, Marco Bechis, 2008), which centres on the violence endured by a contemporary Brazilian Indigenous group attempting to reclaim their traditional lands occupied by agribusiness barons. Based on comparative analysis of Mabo and Terra Vermelha, this article discusses the similar challenges faced by Indigenous nations in these two countries, especially the colonial dispossession of their ancestral territories and the postcolonial obstacles to reclaim and exercise self-determination over them.
\end{abstract}

Keywords: Indigenous Cinema; Land Rights; Australian Cinema; Brazilian Cinema

\section{Introduction}

The article "Discovering White People" written by Indigenous activist Davi Yanomami subverts the standpoint of colonial narratives by placing European peoples as the distant 'Other'. In an anthropological fashion, Yanomani describes the natives of Europe as belonging to a paradoxical culture that is able to produce ingenious machines and material goods, but is doing this at the cost of possibly destroying the planet. To develop his main argument, Yanomami's article emphasises the colonial White-European consumerist relation to lands and natural resources that, according to him, have resulted in increasingly catastrophic consequences for the global environment. Although marked by an apocalyptic tone, his article is a representative account of the idea (subscribed to both by Indigenous and non-Indigenous analysts) that human activities play a central role in climate change (Doran and Zimmerman 22). This is especially the case after the spread of Western industrial-urban models of civilization from the nineteenth century onwards. In line with Yanomami's argument, this article discusses past and present relations between environmentalism and Indigenous struggles. It compares how land rights and sustainability themes overlap in two films: Mabo

\footnotetext{
* Aline Frey is currently a PhD candidate and scholarship holder at the School of Communication and Arts (University of Queensland). Her research focuses on the theme of climate change through the perspective of Indigenous Cinemas in Australia and Brazil. She holds a Master of Arts (MA) in Film and Media Studies from Otago University (Dunedin, New Zealand) and a Graduate Diploma of Arts (Major in Film) from Victoria University of Wellington (New Zealand). Her email address is aline.frey@uq.edu.au
} 
directed by Aboriginal filmmaker Rachel Perkins in Australia and Terra Vermelha directed by ChileanItalian filmmaker Marco Bechis in Brazil.

This article also explores the ways through which these films attempt to communicate the complex relationships many Indigenous peoples have with-and want to continue to have with-natural resources and their traditional lands. A key example to understand this relationship in Australia has been the totem system, which requires individuals/communities to take responsibility for specific living beings and landscapes. ${ }^{2}$ This system of belief connects humanity and nature allowing for a model of "long-term ecological management" that has implications to the whole environment (Rose 127). In Brazil this connection to the land and its preservation is also present among Indigenous groups. The Guarani concept of tekoha, for instance, defined as a sacred territory that needs to be taken care of, allows the Guarani to fulfil their way of life (Melià 36). As such, more than a mere place of origin or residence, the notion of tekoha has a fundamental role in giving meaning to social, economic, politic, religious and cultural aspects of the community. While there is a tendency to view these Indigenous relations to land as a given persisting as they do through time, there is an important way in which these relations are proposed as knowledges and understandings that need to be taken account of-adjusted and calibrated in the polity at large for new circumstances. Rather than being static they are present here as emergent. These debates like the films themselves are part of a public conversation in which Indigenous peoples are interlocutors and agents. As seen later in this article, the importance of traditional lands for Indigenous peoples' physical and cultural survival has placed them on the frontline of environmental debates inside Brazil.

Drawing on the insights of Kerstin Knopf's Decolonizing the Lens of Power (xiv), my close analysis of the films Mabo and Terra Vermelha seeks to avoid an essentialist approach. I am not searching for a supposedly pure and ubiquitous Indigenous aesthetics. Rather, taking my cue from Knopf's study, I acknowledge that Indigenous filmmaking necessarily accommodates complex and hybrid forms in order to dialogue with Western aesthetics and narratives. By adopting Knopf's complex definition I hope to avoid, firstly, reducing contemporary Indigenous' cinema and its diverse practices to a straight jacket of single kinds of films that would hold across Indigenous production in a set of technical and stylistic specificities valid across distinct cultures and places. Secondly, again following Knopf, I want to show (and the comparative analysis is as important here as is the focus on range and variety of indigenous screen activity) how the study of Indigenous films should not aim to confine itself to particularities but to seek the family of connections that a cross-cultural comparison provides.

Knopf (xvi) also points out that, due to the lack of academic framework or terminology for the study of Indigenous cinema, it is still necessary to rely on Western film theories/criticisms. However, in order to avoid hegemonic filmic analysis, she adds that it is also important to investigate films from an interdisciplinary perspective, combining these analyses with postcolonial/decolonialist theories and perspectives emerging from Indigenous studies. It is noteworthy that Knopf is studying North American Indigenous filmmaking in the United States and Canada. In this context, she deals with two neighbouring countries with a higher number of films directed and produced primarily by Indigenous peoples than in Brazil, and with a tradition of filmmaking associated with governmental institutions and anthropological patterns. In contrast, my comparative analyses attempt to bridge Australia, which has relatively well developed Indigenous film production, with Brazil, that is just recently starting to make progress in this field. So, I analyse a film made with the contributions and participation of Indigenous peoples but not necessarily directed or produced by them. In this sense, this article takes into account and theorises the importance of partnership between Indigenous and non-Indigenous peoples in the creation and subsequent interpretation of film meaning. In her report for the then Australian Film Commission, Marcia Langton described "Aboriginality" (82) as the current (efforts of Aboriginal and non-Aboriginal peoples to have an "intercultural dialogue". She argues that this effort is a fundamental path for mutual comprehension 
and interpretation. More than that, Langton sees these "intersubjective exchanges" (83) as crucial for the production of images and contents that go beyond colonialist and Eurocentric representations. As a result, this article acknowledges the role of partnership in the process of decolonising cinema. Aiming to contribute to the field of Indigenous film studies, this article searches for convergences and connections between the audio-visual productions in Australia and Brazil, taking into account decolonialist debates on the themes of Indigenous sovereignty and land rights.

\subsection{Indigenous filmmaking and land disputes in Australia}

The director of Mabo (2012), Rachel Perkins, is a successful Aboriginal filmmaker whose creative career comprises a number of audio-visual productions for cinema and television. ${ }^{3}$ Overall, Perkins's works attempt to portray contemporary issues faced by Aboriginal cultures-and therefore matters of importance for nonAboriginal peoples. They are works whose first audience is "Australian": They are aimed at Aboriginal and nonAboriginal Australia, and they are works of public intervention into different flashpoints of Aboriginalnon-Aboriginal friction. Her works collectively underscore the overlapping feelings of pride and difficulties facing Indigenous peoples living in between Aboriginal and Western cultures. Each are built around the assertion of Aboriginal agency exercised in quite different spheres of life.

In aesthetic terms, Rachel Perkins film' Mabo follows mainstream Hollywood norms, with predictable patterns in terms of mise-en-scène (acting, lighting and setting), camerawork, sound and editing. She also opts for what has been termed as "invisible style of filmmaking" (Lehman and Luhr 59), that is, the strategy of not calling attention to the form in order to leave spectators fully engaged with the film's content. This attempt of not calling attention to the camerawork, making smoothing cuts and applying conventional editing techniques, is so familiar to contemporary spectators used to mainstream Hollywood films that it passes unnoticed. An emotional soundtrack sets the different moods of the film, intensifying spectators' feelings in happy or sad scenes. In this sense, Perkins's direction is marked by a mainstream use of filmic language. In an audio-visual interview about a previous work, Brand Nue Dae (2010), Perkins explains her aesthetic strategies in a way that might help to analyse the options she took in Mabo:

The reason I make indigenous works is to entertain, but also to give understanding and communication across the cultural divide. So I think it's good to have commercial leanings when you are doing an indigenous work because so often our work suffers from not being seen by enough people[...]. I want the work to be seen and be enjoyed. (The Story of Bran Nue Dae)

ABC TV and Blackfella Films produced Mabo. The script was written by Sue Smith, a well-known scriptwriter whose works include the Australian television series Brides of Christ (1991), Leaving of Liverpool (1992) and Bastard Boys (2007). Mabo, similar to other of her scripts, is a factual based drama with social concerns. ${ }^{4}$ Although not innovative in aesthetic terms, Mabo does falls on sub-genre of biopics (biographical films) identified by Dennis Bingham (23) as "minority appropriation", which includes titles such as Malcom $X$. Such films strategically use recognisable Hollywood styles in order to bring to the forefront those who are usually portrayed in marginal or stereotypical roles in mainstream, commercial films. In this sense, Mabo is a rare film because it has an Indigenous person and political activist as the main character. It also has an Indigenous woman as a director that manages to tell and celebrate the overturn of terra nullius in Australia, through an Indigenous perspective.

The legal idea of terra nullius was central to Rachel Perkins's film, as it focuses on the battles of Eddie Koiki Mabo (played by Jimi Bani) against this colonial construct. Terra nullis was widely used to initiate and legitimise a legal system of land tenure from which Aboriginal peoples were excluded. ${ }^{5}$ The concept was not well known until the High Court action of Eddie Koiki Mabo's and most Australians including many in the 
legal profession had not considered how the Australian property system rolled out as it was progressively in several state and territory jurisdictions had its origins in dispossession through terra nullius.

\subsection{The doctrine of Terra Nullius and Land rights in Mabo}

The film shows how the judgment reversed the doctrine of terra nullius and recognised Indigenous ownership of traditional lands in one of the Torres Strait Islands. ${ }^{6}$ Consequently, the victory on the High Court set a precedent for other Indigenous peoples to have their native titles, traditional customs and laws recognised; giving them the necessary legal protection to manage their rights over their land. ${ }^{7}$ Sadly, Eddie Koiki Mabo (1936-1992) did not live to see the conclusion of the case that resulted in the legal recognition of Indigenous land ownership. However, through the establishment of The Native Title Act 1993 (NTA), as an outcome of the Mabo and Others v Queensland case, his name is forever linked to the historical fight for reparation of Indigenous rights. ${ }^{8}$

As said before, Rachel Perkins's film can be defined as a biopic, once it is a film "minimally composed of the life, or the portion of a life, of a real person whose name is used" (Custen 6). Mabo recounts events focusing on an individual's life. It recounts historical episodes through the point of view of one single person and builds on a hero narrative formula, which Bingham (22) calls the "Great Man" film. In this sense, Mabo follows a trend in biographic films, telling the story of a real person through the artifices of childhood flashbacks and voice-overs, while relying on supporting roles of characters that both contribute to and serve as witness to the hero's story.

As in most biopics, the film claims to have a deep connection with reality. It is constructed as a plausible rendering of both man's and nation's history. Although making references to many historical sources such as letters, television footage, testimonies and documents, Mabo is still a fictional work that uses cinematic tools to summarise, in a short and intelligible narrative, the complexity of several decades of a person's life and of a country's history. Considering the inherent limitations of the medium, Mabo does achieve its main goal of fostering an emotional connection between Indigenous and non-Indigenous audiences with the historical man.

As the Mabo court case lasts for almost ten years, the film contextualises Eddie Koiki Mabo biography within important moments of Australian history, such as the rise of the unionist supported movements for Aboriginal recognition and land rights demonstrations after the 1970s. While centring on Mabo's legal case, the film also follows his personal life, especially his deep relationship with his wife Bonita (played by Deborah Mailman). In addition to taking care of their family, the couple also builds a Black community school whose curriculum was centred on local knowledge from the peoples of Murray Island. Bonitas support, especially in looking after the children, was essential to allow Mabo to fight for Indigenous rights. However, Bonita's encouragement was not without anxiety that, by confronting the Australian government, Mabo could be putting his family at risk. During a heated dialogue, for example, Bonita reminds her husband "people like us can't afford to be troublemakers." In turn, Mabo replies: "Bonita, people like us have no choice but to be troublemakers." This dialogue seems to remind viewers that, throughout the history of colonisation in Australia, the denial of Indigenous culture and rights have given them no other option but to struggle against punitive rules established in favour of white settlements.

A key scene of the film is when Mabo, following his father's death, discovers that Australian law does not recognise his family's ownership of the land. Even though he was sure of his ancestral rights, he would need to pursue the challenge of proving his claim in accordance to the rituals and codes of the Western legal system. The clash between the Indigenous peoples' neglected customary rights and the laws enforced by the descendants of white settlers is also shown when Mabo is invited by Professor Noel Loos and Henry Reynolds to give a lecture about Indigenous history at the James Cook University. During the class, he explains that he is a Piadaram man, from one of the eight clans created by Malo, the Octopus God. During Mabo's lecture, a student makes a satirical comment that the land cannot belong 
to him simply because of the wishes of a giant mollusc. On hearing that, Mabo replies that the act of someone planting a flag on the sand cannot erase over sixteen generations of Indigenous occupation of a territory. This conversation summarises the central discussion of Mabo's case: the clash between Indigenous customary conceptions of geography, genealogy, ownership and belonging to the land versus the colonial construct of terra nullius introduced by European settlers.

Mabo is a film that reviews the theme of Indigenous and settlers relationship by celebrating the end of terra nullius as an act of national pride and recognition of Indigenous rights. This is especially clear in the last scene of the film, when, after Mabo's death, Bonita and her son drive from Townsville to Canberra to hear the High Court's final decision on the case. They are not able to arrive in the capital because their car breaks in the middle of the highway. An elderly white Australian couple staying in a campervan shares their radio with them. This act of solidarity underlines the commonality of travel for both Indigenous and non-Indigenous in this instance. Bonita is travelling, meets other travellers, and shares the hospitality and solidarity of groups who are on the road. The group hears the High Court decision, while sitting together on small camping stools. The fact that the couple is camping underlines white Australian's position as temporary settlers of a place that originally did not belong to them. The group commemorates the positive verdict of the Mabo case with hugs and words of congratulation. Firstly, this celebratory encounter between Mabo's family and the old white Australian campers functions as a metaphor of national unity, foretelling an optimistic and harmonious future for the country's different groups if the right decisions are made. Secondly, this meeting amplifies the possibility of improving the relationship between Indigenous and non-Indigenous peoples through the recognition of Indigenous land rights. In fact, since the land rights movement was by then thirty years old in its contemporary form, this has been a longstanding aim rather than a new one. However, Mabo's decision repositioned this claim providing Aboriginal peoples with the legal powers to fight for it independent of the government. Thirdly, this scene reveals the overall mood of the 1990s, following a process of reconciliation that formally began with the creation of the Council for Aboriginal Reconciliation in 1991. The Council had the initial function of helping the country to acknowledge Indigenous dispossession, disadvantage and discrimination and it promulgated 'reconciliation'. Consequently, the appropriation of traditional lands could become part of the national story intrinsic to British colonisation. Also, within a short timeframe of ten years prior to the Federation centenary in 2001, the Council had to progressively ratify economic, social and cultural inequalities historically suffered by Indigenous peoples.

Despite its stated good intentions, Damien Short (35) interprets the Reconciliation process as a way to continue colonial dispossession and acculturation of Indigenous peoples. The author argues that it resulted in the weakening of the increasing Indigenous pressure for a treaty to be signed. The failure of the recognition process was visible after the victory of the Wik peoples of Cape York. In 1996, they went to the High Court and were granted native title even though their land was used in pastoral leases. The impact of this controversial victory led to the Native Title Amendment Act 1998, which basically restricted native title to a level of making impossible for future Indigenous peoples to win a claim. ${ }^{9}$ This outcome, rather them diminishing the importance of Mabo and Wik cases decisions, reinforces them as "highly significant in unsettling the settler state's moral and legal claims to the Australian continent" (Cerwonka 11). The authors of the book, Australian Cinema after Mabo, Collins and Davis (9) argue that the Mabo case decision provoked a "shock of recognition of historical discontinuity". In this line, Perkins's film, released on the $20^{\text {th }}$ anniversary of Mabo case victory, is a strong reminder of the still incomplete process of acknowledgement of Indigenous sovereignty.

Perkins's film finishes with the legal recognition of Indigenous land rights. The message conveyed is one of hope not only for Aboriginal peoples who formally secure their land rights. The film implicitly suggests that non-Aboriginals peoples also benefit from Indigenous occupancy of land, since it has been relatively more sustainable, causing less impact on the environment and natural resources. 
In a similar way to Perkins's Mabo, the feature film Terra Vermelha also focuses on Indigenous peoples' contemporary struggles for land rights, this time in Brazil. As will be shown, the film revolves around the notion that the connection Indigenous peoples have with their traditional territories is not only linked to their present struggles for survival but also to the need to safeguard their ancestors' spiritual bond with the land.

\subsection{Indigenous peoples and Brazilian Cinema: challenges between representation and collaboration}

As in Australia, it took many decades for Indigenous participation in audio-visual productions to shift from exclusively acting roles to directing, writing and producing. In Brazil, this shift seems directly connected to the development and popularisation of first video recording (1980s and 1990s) and then digital (2000s onwards) technologies. In Brazil, Indigenous peoples' attempts to direct and produce their own films began not as individual productions but as collective works. For example, the videos made by Kayapó peoples recorded "their own traditional ceremonies, demonstrations, and encounters with whites" as well as "their traditional knowledge of the forest environment" (Shohat and Stam 36). ${ }^{10}$

In the next section of the article, I undertake a close comparative analysis of the Brazilian-Italian film Terra Vermelha in relation to the Aboriginal production Mabo. As will be seen, in contrast to the latter, the former was not made by but with Indigenous peoples. In contrast to the Australian film industry, which has a relatively long and extensive tradition of Aboriginal film production from the late 1970s early 1980s, Indigenous peoples have yet to solely direct a feature film in Brazil. While Terra Vermelha does not have Indigenous peoples in directing or production roles, it does have a relatively high proportion of Indigenous peoples in the main cast, including the Indigenous activist Ambrósio Vilhalva as the main actor. It makes the film a much-needed addition to the predominantly Euro-descendant dominated Brazilian film industry. As will be detailed, it is also a seminal film in its defiant approach to portraying Indigenous issues in Brazil.

The film was a key work in drawing national and international attention to the current struggles of Guarani-Kaiowás in the south of Brazil. It was a result of a meeting between the film director Marco Bechis and the Guarani-Kaiowás peoples through the office of Nereu Schneider, a human rights lawyer. After the initial contact, Bechis lived two months with Indigenous activist Ambrósio Vilhava, who plays Nádio, the leading character of the film. Indigenous peoples with no previous professional acting experience formed the main cast. During the filming the Indigenous crew was encouraged to collaborate with the script, especially by suggesting changes to make it closer to their way of life. In an interview, the activist and debutant actor Vilhava expressed his motivations to participate in the film as follows: "I always dreamed that one day we could show what our situation is like and tell the story of all of our relatives who have been murdered, mistreated and who have never seen justice". ${ }^{11}$

The Guarani-Kaiowás ancestral lands are situated in a major agribusiness region of contemporary Brazil. The presence of Indigenous peoples on these fertile lands is seen as an impediment to progress by commodity exporters, who have lobbied the government to ignore Indigenous plight and to delay plans to demarcate ancestral territories. Brazilian Euro-descendant farmers in the region have also illegally employed armed gunmen to threaten Guarani-Kaiowás families and even to murder Indigenous leaders. Although the film Terra Vermelha focuses on the specific struggles of contemporary Guarani-Kaiowás in Southern Brazil, it alludes to the ongoing violence and tension that has characterised the relationship between Europeans and Indigenous peoples in the land we know today as Brazil, immemorially known by its Tupi-Guarani through the toponym Pindorama (Land of the Palm Trees).

\subsection{Deforestation and land conflicts in Terra Vermelha}

There were an estimated five million Indigenous peoples in the land known today as Brazil before the 
beginning of the Portuguese colonisation during the sixteenth-century (Garcia 32). According to the 2010 census by the Brazilian Institute of Geography and Statistics (IBGE), there are nearly 900,000 self-declared Indigenous peoples in contemporary Brazil. This accounts for around $0.5 \%$ of the actual national population of almost 200 million. ${ }^{12}$ Although this number is small when compared with the pre-colonial population, there has been a substantial and steady increase in the number of Indigenous peoples when the current census is compared with those of the 1990s and 2000s. Officially, Indigenous peoples in Brazil belong to 305 ethnic groups that speak at least 274 different languages. ${ }^{13}$

Among Brazilian Indigenous peoples, the Guarani are one of the most representative nations of the Americas. This is not just because they have one of the largest populations, but also because their traditional territories extend beyond Brazil's national borders to include Bolivia, Argentina, Paraguay and Uruguay. The Guarani population is divided into several ethnic subgroups such as the Kaiowás, Nandeva and Mbyá. Among them, the Guarani-Kaiowás peoples have made international headlines because of the escalating violence associated with conflicts over land between themselves and cattle ranchers and soy and sugar cane farmers. ${ }^{14}$

While the Guarani-Kaiowás peoples continue to pressure the government to demarcate their tekoha (traditional territory of their ancestors), the state Indigenous agency (FUNAI) gives them the option to move to existing overcrowded reserves nearby. From a Guarani- Kaiowá perspective, however, this is an impossible offer. The tekoha is an extension of the community itself. Both peoples and lands are forever bound together, from previous generations to future ones. Moreover, the areas associated with reserves are too small to offer economic and cultural conditions for their survival. As a result, many decide to live in provisional camps, set up between busy highways and the barbed wire fences of the farms built over their country (Pereira 73). One of the main consequences of this displacement is that suicide rates among Guarani-Kaiowás are higher not only when compared to other Brazilian nationals, but also when compared to the suicide rates of any other populations (Indigenous or not) of any country in the world. In 2000, Guarani-Kaiowás suicide rates were 9\% while in Brazil the rate was less than 1\% (Pan American Health Organization, 2005).

The Guarani-Kaiowás peoples are the main characters in the film Terra Vermelha (Birdwatchers, La Terra Degli Uomini Rossi, Marco Bechis 2008). It is noteworthy that the three different translations of the title into Portuguese, English and Italian each have quite different meanings. The Italian title $\mathrm{La}$ Terra Degli Uomini Rossi ("The land of the Red Men") directly relates Indigenous peoples as the owners of the land. The idea of belonging is reinforced in the implicit association between the redness that characterises the soil of the south of Brazil and the Indigenous tone of skin. Created for European audiences, the Italian title used a familiar colonial trope of the supposed "red" skin of Indigenous peoples (in contrast to the "white" skin of Europeans, black of Africans and yellow of Asians). However, it is important to note the use of this expression is seen by many Indigenous peoples as problematic because of its obvious connection with colonial times. However, in contrast to conventional interpretations, author Nancy Shoemaker (628) argues that the first European colonists actually used other terms, such as "brown of skin" and "tawny", to describe Indigenous populations. She explains that was only in dialogues between Indigenous peoples and English and French explorers, during the eighteenth century, that the term "Red people" begins to appear in historical sources (629). Based on historical evidence, she raises the hypothesis that the expression "red skin" originated from a specific group of Indigenous peoples who coined it as a way to differentiate themselves from European settlers. Accordingly, contrary to Eurocentric narratives, Indigenous peoples were the agents of their own identification, rather then victims of colonial discourse. ${ }^{15}$

In any case, the Italian title may also be interpreted as an attempt to re-appropriate the expression. It certainly reinforces the deep connection between Indigenous peoples and their ancestral land. By contrast, the idea of Indigenous land rights is completely absent from the Portuguese title. Brazilian audiences know the film simply as Terra Vermelha (Red Land). This 
shorter title may have been chosen to underscore the red tonality of Brazilian southwestern lands, especially as a sad reminder of the intense reds of the bare land after deforestation. However, the adjective red is more likely an allusion to the recurrent land conflicts between Indigenous peoples and farmers, which has resulted in the killing of many Indigenous leaders. The shorter title, therefore, is better interpreted as a grievance: that a land is red because it is soaked with and stained by blood. On the other hand, the English title Birdwatchers avoids any reference either to the land or to Indigenous peoples. Rather, it focuses on the tourists that travel to Brazil for the expensive hobby of bird watching. Furthermore, as foreigners visit the forest to watch native birds from a safe distance, the film's title also works as an ironic metaphor of the external gaze that most people have of Indigenous peoples and their issues.

Also, it is unavoidable to relate the title Birdwatchers with a colonial expression Blackbirding. This term is mostly associated to Indigenous' peoples illegal and uncontrolled recruitment to work on sugar and cotton plantations across Australia and Pacific Islands (Connell 137). Although Blackbirding initiated through a phase of kidnapping/forced labour, it was subsequently established as recruitment with very low pay and freedom restrictions. Professor Clive Moore (610) calls these harsh capitalist conditions as "cultural kidnapping", once the lack of information trapped the Islanders into a "legal system operated in their employers' favour". Indeed they were controlled/ restricted in terms of travelling, drinking, buying land, and were exposed to medical treatments-influenced by racist theories and their children forced to education into Christian missions (Moore 610). Coming back to the English title, as the film develops, different from Pacific Blackbirding, the practice of bird watching does not involve any direct interaction with Indigenous peoples. For the tourists who come to Brazil to see native birds in the forest, Indigenous peoples are just part of the landscape. The director depicts tourists displaying a curious but distanced ethnocentric gaze towards Indigenous peoples and struggles.

One of the most threatening contemporary issues for the Guarani-Kaiowás is the increasing suicide rate.
This sensitive theme is referenced in Terra Vermelha during the scene when two Indigenous teenagers, Irineu (Ademilson Concianza Verga) and Osvaldo (Pedro Abrísio da Silva - Guarani name: Chirivy Poty'i), find two girls hanging from the trees. The community gathers for their burial and one of the girls' mothers throws her personal belongings, including a mobile phone and plastic bracelets, inside the pit beside her. These objects may be interpreted as signs of the influence of non-Indigenous society upon the lives of the Indigenous teenagers and the possible negative effects on them. Later, after being reprimanded by his father for wasting money buying fancy sports shoes instead of food, Irineu commits suicide hanging himself in the same way as did the girls. The two scenes draw attention to the negative effects of Western lifestyle over Indigenous societies, such as individualism and consumerism.

Aware of these problems, after the girls' burial, the shaman leader Nhanderu (Nelson Concianza) warns the community to leave the Indigenous reserve and move back to their tekoha (native territory) otherwise they will die. Tekoha is a key word in the film because of the centrality of this concept to Guarani peoples' cosmogony. Tekoha does not only include the physical space, the objects and living beings in contact with past and present Guaranis-including lands, waters, plants and animals. Rather it is also fundamental for Guaranis to accomplish their teko (way of life), once the existence of a sacred territory is a prerequisite for the continuity of their economic, social and religious practices (Dussel 122). Although fundamental for the Guarani survival, they have been displaced from their tekoha, initially by colonial settlers, and in recent times by corporate farmers whose development model is based on the maximum exploitation of natural resources.

In the film, the conflict between these two antagonistic ways of understanding and belonging to a territory is shown in the scene when Nádio (Ambrósio Vilhalva, Guarani name: Kunumi Taperendi) shares with his group the meaning of the word tekoha. While leaning on the fence, Nádio explains that what white farmers see as a commercially lucrative land was actually an invaluable memorial site where their ancestors have been buried and, consequently, where present and 
future generations would also need to be put to rest. Despite Nádio's claims, huge irrigation machines on the background show that the contemporary tekoha is part of a large-scale agribusiness enterprise.

Despite all the risks, the Guarani-Kaiowás group decides to settle alongside their tekoha in provisional camps made of sticks, stones and rough canvases. While the camp is being set up, two Indigenous teenagers, Irineu and Osvaldo, jump over the farm's fence and head to the property's remaining piece of native forest. They go on a hunt to search for food for the rest of the group. However, the only animal that they manage to kill is a runway cow that was hidden in the bush. The shaman leader Nhanderu is not happy after the boys return with their prey. He tries to teach them a lesson by reminding the boys that, although the jaguar and the snake have the power to kill, they are still friends and have lived together with the Guaranis for thousands of years. But he warns that cows should be seen as enemies, because they live off the death and destruction of Indigenous lands. After hearing Nhanderu's tale, the young Osvaldo stubbornly replies that there are no animals left to hunt. During the entire film, there are no images of wild animals. The sterile landscape of the film, in this way, contrasts significantly to the world-famous postcard images of colourful and vibrant Brazilian rainforest flora and fauna. The scenery throughout the film is intentionally monotonous and arid and the only animals constantly caught on camera are the omnipresent cattle. In the film, the once luxurious and bio-diverse Indigenous traditional lands are reduced to a desert occupied by herds of grass-fed cows.

Brazil is a world leader in meat exports (Alexandratos and Bruinsma 2012, 73). Agricultural lands in Southern Brazil, when not used for raising livestock, are generally used to plant soybeans, which is also used as a protein source to feed farm animals. Rich entrepreneurs in the region have been accused of vast deforestation, both for clearing land for extensive farming and for the construction of dams necessary for the development of other industries such as mining. In the film, the dialogue between Nádio and the farmer Moreira underlines the core of the land conflict between Indigenous peoples and farmers. The latter grabs a handful of soil and proudly exclaims that his father arrived at that land more than sixty years ago. He adds that his family has owned the land for three generations, employing money and labour to make it productive. He concludes by saying that his family's ownership of the land also produces food for Brazilians to eat. In reply, but through a silent act, Nádio also grabs soil with his bare hands. But, instead of saying a word, he opens his mouth and eats it. Through this unexpected gesture, he underlines a difference between Indigenous peoples relationship of being intrinsically part of the land versus the distanced and exploitative relation of the farmer with his property. The mute action of the Indigenous leader can be interpreted as a form of shouting to the farmer: while you claim to be the owner of the land, I am the land. The land is not my property. It is an extension of my body.

In Terra Vermelha, in retaliation to the Indigenous group's attempt to remain close to their tekoha, the farmer's private militia murder Nádio. Following the loss of his uncle, a drunk and inconsolable Osvaldo heads to the front of the farmer's house. In cathartic fashion, he screams out that he knows who has ordered Nádio's assassination. After crying out his anger, he walks alone to the forest and tries to commit suicide. However, in the last minute, he gives up by saying out loud: "I won and you lost". By saying these words, Osvaldo is not responding to the farmer but to Angue, a spirit that attacks vulnerable souls. In the film, Angue is depicted as the main figure responsible for the suicides of Irineu and the two girls. Angue targets those who are psychologically fragile or have lost their identity. So, when Osvaldo affirms that he beat Angue, he is stating that he is still strong enough to survive.

The final scene of Terra Vermelha is a panoramic view showing the remaining native forest inside the farm's perimeters. The camera gently follows the treetops until the greenery abruptly stops, revealing a huge deforested area. The aerial shot of a bare red land shows only a single remaining tree standing, surrounded by an eroded desert. The scene draws attention to the analogous condition of Osvaldo and the remaining tree. Both stand alone, uncertain of their survival in face of the ever-growing power of agribusiness in the region. 
Sadly, the scenes of brutality against Indigenous peoples seen in Terra Vermelha are not far from current reality. Thousands of Guarani-Kaiowás peoples are still living in improvised and precarious tents along highways. While under constant psychological and physical threat from farmers, they refuse to leave until they get legal recognition of their land rights. In fact, the tragic stories of some characters are based on real-life events experienced by the actors who interpret them. For example, similar to his character Nádio, the actor Ambrósio Vilhalva was a Guarani-Kaiowá political leader who led struggles for the recognition of his ancestral lands. Unfortunately, just as with his character, his life ended in tragedy soon after the film's release. He was stabbed to death in 2013 for causes that remain unclear but that most likely have to do with his defiant stance he took in relation to the farmers that occupied Guarani-Kaiowás' territory. ${ }^{16}$ As the main advocates for Indigenous rights, Indigenous leaders have been the main targets of violence. By eliminating key leaders, farmers think they will dishearten the community as a whole. So far, this strategy has proved unsuccessful. Despite the collective sorrow, for every Indigenous leader that has fallen, others have risen to follow in their footsteps.

These murders undertaken on behalf of landowners point to one of the differences between Australia and Brazil: the rule of law and the extent of the exercise of that law. In Australia, although "all sorts of private brutality persisted" the last officially recorded murder of political leaders and activists by private militias and individuals occurred during the Coniston Massacre in 1928 (Reynolds 49). Indeed, the central issue in Australia is Indigenous peoples deaths in custody. This is directed related to a disproportional number of Indigenous prisoners taking into account its small population in Australia. ${ }^{17}$ In Brazil, the death through murder and assassination by private sector actors is also not official but recurrent. This is mainly due to the inconsistencies between the law system and government policies. Indeed, in Brazil, the state is often incompetent or unwilling to enforce the laws related to Indigenous customary rights. As written in the 1988 Brazilian Constitution, Indigenous lands are considered to be those territories:
Traditionally occupied by indigenous people in permanent fashion, those utilised for productive activities, those necessary to the preservation of natural resources on which they depend, and those necessary to their wellbeing, and physical and cultural reproduction, according to their habits and tradition. (Qtd. in Carvalho 468)

However, the inclusion and acknowledgement of constitutional Indigenous rights has not always resulted in the formal/effective demarcations of lands. This contrast between written laws and law enforcement cannot be understood without considering the lobbying by mining companies and farmers-many of whom occupy strategic government positions as congressmen and ministers-with high interest in appropriating Indigenous lands. By opposing these peddling interests, Indigenous peoples have been even more successful than have those responsible for uninhabited parks in protecting tropical forests and pausing deforestation (Schwartzman, Moreira and Nepstad 1352).

\subsection{The struggle for land rights across Indig- enous nations}

Mabo and Terra Vermelha have similar opening sequences: an aerial view of their main stages. In the case of Mabo, just after television footage of the historical High Court decision, the film shows a panoramic view of Eddie Koiki Mabo's homeland, Murray Island. There, the young Mabo learns from his father the first lessons about the importance of living in the traditional way, particularly the importance of fishing and farming for survival. In Birdwatchers, the opening scene is a bird's eye perspective of the tropical rainforest. Initially, the Indigenous characters appear to be living in the traditional way, living in a natural environment and out of reach from urban influence. However, this romantic portrayal rapidly changes in the following scene; when they remove their "traditional indigenous outfits" and receive payment for their touristic performance. Although each film uses a different approach, both deal with the complex theme of tradition and its maintenance in the present.

Australia has a considerably higher number of Indigenous films than has Brazil. However, in both 
countries, Indigenous audio-visual self-representation is not yet at the same level as mainstream media representation of Indigenous groups. This is especially true considering the numbers of films made and funding received by Indigenous and non-indigenous directors. The large number of images and content produced by state and corporate-owned media did not decline after the growth of Indigenous self-representation. Regarding this theme, the Aboriginal scholar Marcia Langton points out:

It is clearly unrealistic for Aboriginal people to expect that others will stop portraying us in photographs, films, on television, in newspapers, literature and so on. Increasingly, non-Aboriginal people want to make personal rehabilitative statements about the Aboriginal problem and to consume and reconsume the primitive [...]. Rather than demanding an impossibility, it would be more useful to identify those points where it is possible to control the means of production and to make our own self-representations. (26)

On the other hand, it is necessary to point out that Indigenous representations are not essentially good in themselves. After all, Indigenous self-representations are not necessarily exempt of falling into common racist or sexist stereotypes found in mainstream media. For example, although the strong relationship between Mabo and Bonita is emotionally moving and important to explain his activism, it also reinforces traditional phallocentric hero narratives. In this sense, Indigenous media faces the same challenge as non-Indigenous filmmakers: to maintain critical positions of its own productions.

\section{Conclusion}

This article discussed how recent Brazilian and Australian films have portrayed differences between how Indigenous peoples and Euro-descendants understand the theme of land rights. This does not mean that all Indigenous or all Euro-descendants behave in oppositional ways. However, as seen, cinematic productions tend to contrast Indigenous and European- coloniser views by underscoring two antithetical relationships: whereas for the former land ownership directly relates to a sense of belonging through ancestral and cultural connections, for the latter it is a matter of acquired property and economic production.

In this line, the main argument of this article is that these distinct connections are perceived as resulting in opposite ways of managing the land. For example, over a long period of time, the coloniser's approach to managing the land is associated as the main cause for a series of environmental problems such as deforestation. On the other hand, Indigenous practices of forest clearing to grow crops in a system of shifting cultivation have been seen as sustainable and ecologic. As professor Ramakrishnan (197) states, "the scientific community at large is now seeing the need for a community-linked and value-system-based approach to land-use development, with concerns for biodiversity conservation." The issue of land management not only persisted into contemporary settings but it increased with economic incentives for remaking whole landscapes through large-scale deforestation.

The close analysis of Mabo and Terra Vermelha touched on similar issues, especially because these films put forward the argument that Indigenous peoples have a more sustainable-traditional relation with natural resources and lands. In this sense, these films reinforce the idea that Indigenous peoples know how to live from natural resources without destroying and polluting the planet. For this reason, both films endorse the argument that most of the world's remaining natural resources should be under Indigenous lands and protection precisely because their cultures avoid predatory exploration.

In this article, I touched on two key questions: firstly, can Indigenous peoples' ways of life offer contributions to the global debates on environmental crises? And secondly, how are cinema productions in Brazil and Australia portraying Indigenous peoples as protagonists for solving contemporary environmental issues? These interrelated themes are particularly relevant inside postcolonial nations, which have multicultural societies and tend to be vulnerable to world markets that favour environmental exploitation 
and therefore environmental "make-overs" at significant scales as part of never-ending calls for more development as pathways for economic participation and global integration. However, simultaneous with the growth of these global economic pressures, local resistance, particularly Indigenous resistance also gains strength. It too is connected with different kinds of global pressures towards sustainability and environmental protection that deftly connects with Indigenous agenda and struggles. This antagonistic relation between local and global agendas was central to the close analyses of the films of Indigenous cinema in Australia and Brazil.

\section{Notes}

1. This extract is cited in Stam and Shohat (11). Davi Yanomami gained fame around the world as a spokesperson of Indigenous struggles for land rights recognition in Brazil. He was one of the main leaders in the successful efforts of the demarcation of Yanomamis traditional territory in the 1980s.

2. According to Newsome (327), the preservation of the Red Kangaroo is deeply connected with the existence of Aboriginal sacred sites in Central Australia. His studies confirmed that, in the middle of the desert, these sites coincide with an oasis that gathers together a great number of Red Kangaroos during drought periods. As these sacred areas are restricted from hunting, burning and even harvesting, they offer essential resources for these animals during periods of scarce food and water.

3. It is noteworthy that Rachel Perkins is the daughter of Aboriginal activist and soccer player Charles Perkins (1936-2000). He was the first Aboriginal person to obtain a graduate degree and is well known for organising, together with a group of interracial Australian students, the 'Freedom Ride' (1965). This was a bus trip across the countryside of New South Wales' towns to denounce segregation laws that restricted the access of Indigenous peoples to public spaces such as swimming pools, clubs, hotels and theatres. This was a successful grassroots enterprise, especially because Perkins and the students managed to call attention of the media, which gave them a positive coverage and, consequently, put local racism on the national agenda (Curthoys 274).

4. These two mini-series were landmarks in Australian television during 1990s: Brides of Christ (1991) was set in a convent school, showing the conflicts and doubts of a group of students and their religious teacher during the turbulent 1960s. Leaving of Liverpool (1992) focuses on the child migrant scheme revealing slave labour and systemic abuse of children by church members during the orphanage. http://aso.gov.au/people/ Sue_Smith/, Accessed $4^{\text {th }}$ June 2015. This interview with Rachel Perkins explains the choice of Sue Smith as screenwriter, alluding to her previous works based on historical facts, which aimed to balance narratives of private and public life. http://www.abc.net.au/tv/ mabo/videos/?play=mabo_webex_writingresearch. mp4, Accessed $10^{\text {th }}$ June 2015.

5. The Latin expression Terra nullius "means either a country without a sovereign or a land that is not owned" (Behrendt 1995, 2). Under the justification of not recognising Aboriginal law, the British Empire settled in Australia ignoring the already existent Indigenous legal system as well as their ownership of the land.

6. Although a framework for land rights legislation had been developed since the mid-1970s and had been unevenly rolled out-mostly in the Northern Territory-before Mabo, different states had developed some of their own "versions" of land rights. Mabo intensified and redefined these creating a right that was inherent rather than legislated.

7. On the other hand, there were also legal cases in which ethnographic materials were used to delegitimise the claims of Indigenous peoples to traditional ownership of lands. For example, during native title claim in Victoria, in 1998, the Yorta Yorta Aboriginal group tried to prove their historical occupation of lands based on a comprehensive use of testimonies, storytelling, interviews and other oral history sources. However, Indigenous sources were seen as incomplete and untrustworthy, especially because they were not corroborated by European documents. To make things worse for the Yorta Yorta claimants, European-made written sources were used against them to prove that they did not live in the same traditional way as their Yorta Yorta ancestors and, therefore, had no right to claim ownership to their ancestral lands (MoretonRobinson 3).

8. Mabo v Queensland (No 2) [1992] HCA 23; (1992) 175 CLR 1 (3 June 1992), accessed on $12^{\text {th }}$ May 2015. http://www.austlii.edu.au/cgibin/sinodisp/au/cases/ cth/HCA/1992/23.html?stem $=0$ \&synonyms $=0$ \&query =title (mabo\%20\%20near\%20\%20queensland)

9. The Native Title Amendment Act 1998 was part of a ten-point plan of Prime Minister John Howard, which applied "massive curtailments of the hard-won land rights", enabling state Governments to validate and extend mining and pastoral leases (Strang 109).

10. Vast material has been produced in partnership with non-Indigenous peoples since 1980s. Examples are projects such as Video in the Villages (1987) that 
has already a robust production of shorts-films and documentaries. In Australia, this has its parallels in community authorised and enacted films such as Two Laws, made in collaboration with the Borroloola Aboriginal Community and based on their oral storytelling, and the video work celebrated by Eric Michaels in For a Cultural Future: Frances Jupurrurla Makes TV at Yuendumu (Sydney: Artspace, Art and Criticism Series, v. 3, 1987)

11. Tom Phillips, The Guardian, 11 September 2009 http://www.theguardian.com/film/2009/sep/11/ birdwatchers, accessed 20th January 2015.

12. IBGE, Demographic Census (1991/2010), http://cod. ibge.gov.br/233DQ, accessed on 14th October 2015.

13. IBGE explains that this increase results not only from demographic growth, but also from the increasing number of people, especially in urban areas, who now self-identify themselves as Indigenous peoples. http:// cod.ibge.gov.br/233E5, accessed on 14th October 2015.

14. "Brazil indigenous Guarani leader Nisio Gomes killed”. BBC NEWS, 19 November 2011, http://www. bbc.com/news/world-latin-america-15799712, accessed on 12 December 2014. Osmair Martins Ximenes: "Brazilian Guarani tortured and murdered". Survival International, 22 December 2009. http://www. survivalinternational.org/news/5389, accessed on 14 December 2014. Genivaldo Vera: "Indigenous teacher missing in Brazil after violence over ancestral lands." Amnesty International, 13 November 2009. http://www. amnesty.org/fr/node/14040, accessed on 14 December 2014. Ortiz Lopes: “The Independent Reports: Brazil's Deadly Land Wars put Indigenous Leaders in Firing Line". The Independent, 23 July 2007, http://www. mstbrazil.org/news/07232007-independent-reportsbrazils-deadly-land-wars-put-indigenous-leadersfiring-line, accessed on 14 December 2014. Kuretê Lopez: "Guarani Indian woman killed by gunman". Survival International, 12 January 2007. http://www. survivalinternational.org/news/2157, accessed on 14 December 2014. Chief Marcos Verón: "Brazilian Indian leader who died fighting for his people's rights". The Guardian, Tuesday 28 January 2003. http://www.theguardian.com/news/2003/jan/28/ guardianobituaries, accessed 12 December 2014.

15. Nancy Shoemaker (626) does a comparative analysis between Indigenous peoples in the Northeast and Southeast of the United States. She develops two hypotheses in order to explain the origins of why Indigenous peoples were called "red" peoples. In both, she argues that Indigenous peoples were responsible for calling themselves "red" skins. The first hypothesis was that they claimed to be "red" in order to differentiate themselves from the European peoples, who self-declared themselves as "white" and Africans slaves as "black". The second hypothesis suggests that some Indigenous groups were already being called as "red" by other Indigenous peoples, before European colonisation. In both cases, the author claims that red was a "logical category" conveniently adopted by Indigenous peoples from the past and also in the present as a way of uniting a heterogeneous group of peoples (629). However, the author points that this does not mean that the association with red skin is not contested nowadays, as the white settlers appropriated the term and gave its current depreciative meanings and uses, such as in the ongoing debates about the name of the US football team, Washington Redskins.

16. “Ambrósio Vilhava, 1960-2013 - an obituary". $11^{\text {th }}$ December 2013. http://www.survivalinternational. org/news/9826 accessed $20^{\text {th }}$ January 2015.

17. A Royal commission was created to investigate Aboriginal deaths in custody from 1980-1989. The RCIADIC findings exposed the alarming "Indigenous inequality before the law" (Wilkie and Brown 2002, 25). It showed that, although the Aboriginal population is only about $1.1 \%$ of Australia's total population, it composes $29 \%$ of prisoners. It made 339 recommendations to prevent Aboriginal deaths in custody. However, these have not been successfully adopted. A later report on Indigenous Deaths in Custody 1989-1996 continues to show that: "Indigenous people are twice as likely as non-Indigenous people to be arrested in circumstances where assault occasioning no harm is the most serious offence. They are three times more likely to be imprisoned for such an offence. This indicates that provocative policing is continuing through the use of the trifecta (offensive language, resist arrest and assault occasioning no harm)". Accessed 2nd June 2015, https://www.humanrights. gov.au/social_justice/publications/deaths_custody/ report_summary.html.

\section{References}

Alexandratos, N. and J. Bruinsma. World agriculture towards 2030/2050: the 2012 revision. ESA Working paper No. 12-03. Rome, FAO. June 2012. Web.

Behrendt, Larissa. Aboriginal Dispute Resolution: A Step Towards Self-Determination and Community Autonomy. Annandale, N.S.W: The Federation Press, 1995. Web.

Bingham, Dennis. Whose Lives Are They Anyway?: The Biopic as Contemporary Film Genre. New Brunswick, N.J: Rutgers University Press, 2010. Web.

Carvalho, Georgia O. "The Politics of Indigenous Land Rights in Brazil". Bulletin of Latin American Research. 19.4 (Oct., 2000): 461-478. 
Cerwonka, Allaine. Native to the Nation: Disciplining Landscapes and Bodies in Australia. Minneapolis, MN: University of Minnesota Press, 2004. Print.

Collins, Felicity, and Therese Davis. Australian Cinema After Mabo. Cambridge: Cambridge University Press, 2004. Print.

Connell, John. "Blackbird Labor Trade." Encyclopedia of Western Colonialism since 1450. Ed. Thomas Benjamin. Vol. 1. Detroit: Macmillan Reference USA, 2007. 137138. Gale Virtual Reference Library. Web. 13 Feb. 2015.

Curthoys, Ann. Freedom Ride: A Freedom Rider Remembers. Crows Nest, N.S.W: Allen \& Unwin, 2002. Web.

Custen, George Frederick. Bio/pics: How Hollywood Constructed Public History. New Brunswick, N.J: Rutgers University Press, 1992. Web.

Doran, Peter T., and Maggie Kendall Zimmerman. "Examining the Scientific Consensus on Climate Change." Eos, Transactions American Geophysical Union. 90.3 (2009): 22. Web.

Dussel, Enrique D. 1492: El Encubrimiento Del Otro : (Hacia El Origen Del "Mito De La Modernidad") : [Conferencias De Frankfurt, Octubre De 1992]. Madrid: Editorial Nueva Utopía, 1992.

Garcia, Beatriz. The Amazon from an International Law Perspective. Cambridge: Cambridge University Press, 2011.

Knopf, Kerstin. Decolonizing the Lens of Power. Amsterdam - New York: Editions Rodopi B.V, 2008. Print.

Langton, Marcia. Well, I Heard it on the Radio and I Saw it on the Television: An Essay for the Australian Film Commission on the Politics and Aesthetics of Filmmaking by and about Aboriginal People and Things. Sydney: Australian Film Commission, 1993. Print.

Lehman, Peter, and William Luhr. Thinking about Movies: Watching, Questioning, Enjoying. 3rd ed. Malden, MA: Blackwell Pub, 2008. Print.

Mabo, Director: Rachel Perkins - 2012. Film.

Malcom X, Director: Spike Lee, Denzel Washington and Angela Bassett - 1992. Film.

Melià, Bartomeu. "A terra sem mal dos Guarani: economia e profecia”, Revista de Antropologia. São Paulo. 33 (1990): 33-46. Web.

Moore, Clive. Kanaka Maratta: A History of Melanesian Mackay. Townsville: James Cook University of North Queensland, 1981.

Moreton-Robinson, Aileen M. "The Possessive Logic of Patriarchal White Sovereignty: The High Court and the Yorta Yorta decision." Borderlands e-journal. 3.2 (2004).
Newsome, A. E. “The Eco-Mythology of the Red Kangaroo in Central Australia." Mankind 12.Dec 1980 (1980): 327. Web.

Pereira. Levi. "Assentamentos e formas organizacionais dos Kaiowá atuais: o caso dos "índios de Corredor"”. Teflus. Ano 6.10. 69-81. (Abr. 2006). Campo Grande - MS.

Ramakrishnan, P. S., "Shifting Agriculture and Fallow Management Options. Where do we stand?" Malcolm Cairns. Shifting Cultivation and Environmental Change: Indigenous People, Agriculture and Forest Conservation. Abingdon, Oxon; New York;: Routledge, 2015. Web.

Reynolds, Henry. Forgotten War. Sydney, N.S.W: NewSouth Publishing, 2013.

Rose, Deborah Bird. "Common Property Regimes in Aboriginal Australia”. Larmour, Peter. The Governance of Common Property in the Pacific Region. Canberra, ACT: ANU E Press, 2013. Web.

Schwartzman, S., Nepstad, D., \& Moreira, A. "Rethinking Tropical Forest Conservation: Perils in Parks. Conservation Biology. 14:5 (2000): 1351-1357. Web.

Short, Damien. Reconciliation and Colonial Power: Indigenous Rights in Australia. Burlington, VT; Aldershot, England;: Ashgate, 2008. Web.

The Story of Bran Nue Dae. Dir. Adrian Wills. Roadshow Entertainment, 2010. DVD.

Two Laws. Dir. Borroloola Aboriginal Community with Carolyn Strachan and Alessandro Cavadini,1981, FACETS, 2008. DVD.

Shoemaker, Nancy. "How Indians Got to be Red." The American Historical Review. 102.3 (1997): 625-44. Web.

Shohat, Ella, and Robert Stam. Unthinking Eurocentrism Multiculturalism and the Media. New York: Routledge, 2014. Web.

Stam, Robert, and Ella Shohat. Race in Translation: Culture Wars Around the Postcolonial Atlantic. 1st ed. New York: New York University Press, 2012;1998. Web.

Strang, Veronica. "Not so Black and White: The Effects of Aboriginal Law on Australian Legislation". Abramson, Allen, and Dimitrios Theodossopoulos. Land, Law and Environment: Mythical Land, Legal Boundaries. London: Pluto, 2000. Web.

Terra Vermelha. Director Marco Benchis - 2008. Film.

Yanomami, Davi Kopenawa. "Discovering White People" cited in Shohat, Ella, and Robert Stam. Unthinking Eurocentrism: Multiculturalism and the Media. New York: Routledge, 2014. Web.

Recebido em: 29/02/2016 Aceito em: 28/03/2016 